\title{
Pengaruh Akses Media terhadap Status Imunisasi Dasar pada Anak di Indonesia
}

\author{
Nia Musniati ${ }^{*}$, Izza Suraya ${ }^{2}$, Yoli Farradika ${ }^{3}$, Elia Nur A'yunin ${ }^{4}$, Hidayati $^{5}$ \\ ${ }^{1)}$ Program Studi Kesehatan Masyarakat, Fakultas Ilmu-Ilmu Kesehatan, Universitas Muhammadiyah Prof. \\ DR. HAMKA, niamusniati@uhamka.ac.id \\ ${ }^{2)}$ Program Studi Kesehatan Masyarakat, Fakultas Ilmu-Ilmu Kesehatan, Universitas Muhammadiyah Prof. \\ DR. HAMKA, izza_suraya@uhamka.ac.id \\ ${ }^{3)}$ Program Studi Kesehatan Masyarakat, Fakultas Ilmu-Ilmu Kesehatan, Universitas Muhammadiyah Prof. \\ DR. HAMKA, yoli.farradika@uhamka.ac.id \\ ${ }^{4)}$ Program Studi Kesehatan Masyarakat, Fakultas Ilmu-Ilmu Kesehatan, Universitas Muhammadiyah Prof. \\ DR. HAMKA, elianurayunin@uhamka.ac.id \\ ${ }^{5}$ Program Studi Kesehatan Masyarakat, Fakultas Ilmu-Ilmu Kesehatan, Universitas Muhammadiyah Prof. \\ DR. HAMKA, hidayati@uhamka.ac.id

\begin{abstract}
ABSTRAK
Pada tahun 2018, diperkirakan 19,4 juta bayi di seluruh dunia tidak tercapai dengan layanan imunisasi dasar. Sekitar 60\% dari anak-anak ini tinggal di 10 negara: Angola, Brasil, Republik Demokratik Kongo, Ethiopia, India, Indonesia, Nigeria, Pakistan, Filipina, dan Vietnam. Tujuan penelitian ini adalah untuk mengetahui pengaruh akses media terhadap status imunisasi dasar di Indonesia. Penelitian ini dilaksanakan menggunakan desain crosssectional dengan menganalisis lanjut data SDKI Indonesia tahun 2017. Penelitian dilakukan dari Januari hingga Maret 2020. Jumlah sampel yang digunakan adalah 6483 orang ibu yang memiliki anak usia 12-23 bulan dengan teknik sampel jenuh. Pengolahan dan analisis data menggunakan SPSS dan analisis data yang dilakukan adalah analisis univariat, bivariat menggunakan uji Chi Square dan multivariat menggunakan uji Regresi Logistik Berganda. Hasil bivariat menunjukkan bahwa terdapat hubungan yang bermakna antara membaca surat kabar, menonton televisi, frekuensi akses internet dengan status imunisasi dasar di Indonesia $(P$-value $<0,05)$. Hasil multivariat menunjukkan ada hubungan yang bermakna antara menonton televisi dan frekuensi akses internet dengan status imunisasi dasar (P-value <0,05). Variabel yang paling dominan atau paling berpengaruh terhadap status imunisasi dasar di Indonesia adalah menonton televisi dengan OR=2,268 (1,754-2,931). Saran dari penelitian ini adalah pemerintah terus menggalakkan sosialisasi yang akurat tentang pentingnya imunisasi dasar di berbagai media, khususnya di media televisi.
\end{abstract}

Kata kunci: surat kabar, radio, televisi, internet, imunisasi dasar

\begin{abstract}
In 2018, an estimated 19.4 million babies worldwide will not be achieved with basic immunization services. About 60\% of these children live in 10 countries: Angola, Brazil, Democratic Republic of the Congo, Ethiopia, India, Indonesia, Nigeria, Pakistan, the Philippines, and Vietnam. This study aimed to determine the effect of media access on basic immunization status in Indonesia. This study was carried out using a cross-sectional design by further analyzing Indonesian IDHS data for 2017. The study was conducted from January to March 2020. The number of samples used was 6483 mothers who had children aged 12-23 months with a saturated sample technique. Data processing and analysis using SPSS and data analysis performed was univariate analysis, bivariate using Chi Square test, and multivariate using the Multiple Logistic Regression test. Bivariate results show a significant relationship between reading newspapers, watching television, and frequency of internet access with basic immunization status in Indonesia (P-value $<0.05)$. Multivariate results showed a significant relationship between watching television and frequency of internet access with basic immunization status $(P$-value $<0.05)$. The most dominant or most influential variable on Indonesia's basic immunization status is watching television with OR = 2,268 (1,754-2,931). Suggestions from this research are that the government promotes proper socialization about the importance of basic immunization in various media, especially in television media..
\end{abstract}

Keywords : newspapers, radio, television, internet, basic immunization

*Korespondensi Author : Nia Musniati, Program Studi Kesehatan Masyarakat Fakultas Ilmu-Ilmu Kesehatan Universitas Muhammadiyah Prof.DR.HAMKA, niamusniati@uhamka.ac.id,Telp.081283899487. 


\section{PENDAHULUAN}

Imunisasi saat ini mencegah 2-3 juta kematian setiap tahun. Imunisasi mencegah kematian setiap tahun di semua kelompok umur akibat penyakit seperti difteri, tetanus, pertusis (batuk rejan), influenza dan campak. Ini adalah salah satu intervensi kesehatan masyarakat yang paling berhasil dan hemat biaya. Selama dua tahun terakhir dunia telah melihat beberapa wabah campak, difteri dan berbagai penyakit lain yang dapat dicegah dengan vaksin. Sebagian besar anak-anak yang meninggal adalah mereka yang tinggal di komunitas yang paling miskin, terpinggirkan dan terkena dampak konflik. Selain itu, terdapat hampir 20 juta anak yang tidak divaksinasi dan kurang divaksinasi di dunia serta diperkirakan 19,4 juta anak di bawah usia satu tahun tidak menerima vaksin dasar. ${ }^{1}$

Memperluas akses ke imunisasi sangat penting untuk mencapai tujuan pembangunan berkelanjutan (SDGs). Vaksinasi tidak hanya mencegah penyakit dan kematian yang terkait dengan penyakit menular seperti campak, radang paru-paru, polio dan batuk rejan, tetapi juga memegang keuntungan yang lebih luas dalam pendidikan dan pembangunan ekonomi kedepan. Selain itu, status imunisasi juga merupakan salah satu faktor risiko pneumonia pada balita. Pneumonia merupakan penyebab kematian terbesar pada balita di seluruh dunia. Pada tahun 2017, pneumonia membunuh 808.694 anak di bawah usia 5 tahun, terhitung $15 \%$ dari semua kematian anak di bawah lima tahun. Ini dibuktikan oleh hasil penelitian Musniati (2018), yang menemukan hubungan yang signifikan antara status imunisasi dengan pneumonia (Pvalue 0,004, OR 95\% CI 5,163 (1,704-15.648), yang artinya balita yang memiliki status imunisasi tidak lengkap berisiko 5,163 kali menderita pneumonia dibandingkan balita yang memiliki status imunisasi lengkap. . $^{2,3,4}$

Pada tahun 2018, diperkirakan 19,4 juta bayi di seluruh dunia tidak tercapai dengan layanan imunisasi dasar. Sekitar 60\% dari anakanak ini tinggal di 10 negara: Angola, Brasil, Republik Demokratik Kongo, Ethiopia, India, Indonesia, Nigeria, Pakistan, Filipina, dan
Vietnam. Berdasarkan hasil Riset Kesehatan Dasar (RISKESDAS) tahun 2013, menunjukkan cakupan imunisasi dasar di Indonesia hanya $59,2 \%$. Ketidaktercapaian layanan imunisasi dasar tersebut salah satunya dapat disebabkan oleh kurangnya informasi terkait imunisasi. Informasi tersebut dapat di akses melalui berbagai media. Sayangnya, sampai saat ini, belum terdapat studi yang mengkaji hubungan kelengkapan imunisasi dasar dengan akses media. Oleh karena itu, penelitian ini dilakukan untuk mengetahui pengaruh media terhadap status imunisasi dasar di Indonesia. ${ }^{1,19}$

\section{METODOLOGI}

Penelitian ini menggunakan desain cross sectional dengan melakukan analisis lanjut menggunakan data sekunder dari data Survei Demografi dan Kesehatan Indonesia (SDKI) tahun 2017. SDKI 2017 dilaksanakan bersama oleh BPS, BKKBN dan Kementerian Kesehatan. Pengumpulan data SDKI dilakukan Juli hingga September 2017.

Populasi pada Penelitian ini adalah semua ibu yang memiliki balita umur 12-23 bulan. Seluruh anggota populasi 17.848 orang diikutsertakan, namun 11.001 orang ibu yang tidak mempunyai catatan imunisasi dalam database SDKI dikeluarkan, setelah itu, 120 orang lainnya juga dikeluarkan karena mempunyai data karakteristik yang tidak lengkap. Selanjutnya dilakukan pembobotan, sehingga jumlah sampel menjadi 6483 orang anak. Teknik sampel yang digunakan adalah purposive sampling. Pengolahan dan analisis data dengan SPSS. Analisis data yang dilakukan adalah univariat, bivariat dan multivariat. Karena data berjenis kategorik, sehingga analisis bivariat menggunakan uji chi square, dan multivariat dengan uji regresi logistik berganda.

\section{HASIL DAN PEMBAHASAN}

Hasil penelitian menunjukkan sebagian besar responden memiliki status imunisasi dasar lengkap (67,9\%), imunisasi BCG (91,3\%), imunisasi DPT 1 (90,0\%), imunisasi DPT 2 $(85,6 \%)$, imunisasi DPT $3(78,9 \%)$, polio 0 $(91,6 \%)$, polio $1(89,9 \%)$, polio $2(84,7 \%)$, polio 
$3(74,9 \%)$, dan imunisasi campak $(82,2 \%)$ (tabel 1). Selain itu, sebagian besar responden memiliki keluarga yang tidak pernah membaca surat kabar $(62,7 \%)$, tidak mendengarkan radio (62,6\%), 1 kali seminggu menonton televisi $(84,7 \%)$, frekuensi akses internet yang tidak pernah $(55,0 \%)$ (tabel 2).

Tabel 1. Distribusi Responden Berdasarkan Imunisasi Dasar di Indonesia tahun 2017

\begin{tabular}{|c|c|c|c|}
\hline No & Variabel & n & $\%$ \\
\hline \multirow[t]{4}{*}{1} & Status imunisasi & & \\
\hline & Tidak lengkap & 2084 & 32,1 \\
\hline & Lengkap & 4399 & 67,9 \\
\hline & Total & 6483 & 100 \\
\hline \multirow[t]{4}{*}{2} & Imunisasi BCG & & \\
\hline & Tidak & 565 & 8,7 \\
\hline & $\mathrm{Ya}$ & 5919 & 91,3 \\
\hline & Total & 6483 & 100 \\
\hline \multirow[t]{4}{*}{3} & Imunisasi DPT 1 & & \\
\hline & Tidak & 652 & 10,0 \\
\hline & $\mathrm{Ya}$ & 5832 & 90,0 \\
\hline & Total & 6483 & 100 \\
\hline \multirow[t]{4}{*}{4} & Imunisasi DPT 2 & & \\
\hline & Tidak & 930 & 14,4 \\
\hline & $\mathrm{Ya}$ & 5553 & 85,6 \\
\hline & Total & 6483 & 100 \\
\hline \multirow[t]{4}{*}{5} & Imunisasi DPT 3 & & \\
\hline & Tidak & 1367 & 21,1 \\
\hline & $\mathrm{Ya}$ & 5116 & 78,9 \\
\hline & Total & 6483 & 100 \\
\hline \multirow[t]{4}{*}{6} & Imunisasi Polio 0 & & \\
\hline & Tidak & 542 & 8,4 \\
\hline & $\mathrm{Ya}$ & 5942 & 91,6 \\
\hline & Total & 6483 & 100 \\
\hline \multirow[t]{4}{*}{7} & Imunisasi Polio 1 & & \\
\hline & Tidak & 652 & 10,1 \\
\hline & $\mathrm{Ya}$ & 5832 & 89,9 \\
\hline & Total & 6483 & 100 \\
\hline \multirow[t]{4}{*}{8} & Imunisasi Polio 2 & & \\
\hline & Tidak & 995 & 15,3 \\
\hline & $\mathrm{Ya}$ & 5488 & 84,7 \\
\hline & Total & 6483 & 100 \\
\hline \multirow[t]{4}{*}{9} & Imunisasi Polio 3 & & \\
\hline & Tidak & 1629 & 25,1 \\
\hline & $\mathrm{Ya}$ & 4854 & 74,9 \\
\hline & Total & 6483 & 100 \\
\hline \multirow[t]{4}{*}{10} & Imunisasi & & \\
\hline & Campak & & \\
\hline & Tidak & 1157 & 17,8 \\
\hline & $\mathrm{Ya}$ & 5327 & 82,2 \\
\hline
\end{tabular}

\begin{tabular}{llll}
\hline No & Variabel & n & \% \\
\hline & Total & 6483 & 100 \\
\hline
\end{tabular}

Tabel 2. Distribusi Responden Berdasarkan Akses Media di Indonesia tahun 2017

\begin{tabular}{|c|c|c|c|}
\hline No & Variabel & $\mathbf{n}$ & $\%$ \\
\hline \multirow[t]{5}{*}{1} & Membaca surat kabar & & \\
\hline & Tidak pernah & 4067 & 62,7 \\
\hline & $\begin{array}{l}\text { Kurang dari } 1 \text { kali } \\
\text { seminggu }\end{array}$ & 1860 & 28,7 \\
\hline & 1 kali seminggu & 557 & 8,6 \\
\hline & Total & 6483 & 100 \\
\hline \multirow[t]{5}{*}{2} & Mendengarkan radio & & \\
\hline & Tidak pernah & 4060 & 62,6 \\
\hline & $\begin{array}{l}\text { Kurang dari } 1 \text { kali } \\
\text { seminggu }\end{array}$ & 1706 & 26,3 \\
\hline & 1 kali seminggu & 717 & 11,1 \\
\hline & Total & 6483 & 100 \\
\hline \multirow[t]{5}{*}{3} & Menonton televisi & & \\
\hline & Tidak pernah & 250 & 3,9 \\
\hline & $\begin{array}{l}\text { Kurang dari } 1 \text { kali } \\
\text { seminggu }\end{array}$ & 743 & 11,5 \\
\hline & 1 kali seminggu & 5491 & 84,7 \\
\hline & Total & 6483 & 100 \\
\hline \multirow[t]{6}{*}{4} & Frekuensi akses internet & & \\
\hline & Tidak pernah & 3567 & 55,0 \\
\hline & $\begin{array}{l}\text { Kurang dari } 1 \text { kali } \\
\text { seminggu }\end{array}$ & 193 & 3,0 \\
\hline & 1 kali seminggu & 640 & 9,9 \\
\hline & Hampir setiap hari & 2084 & 32,1 \\
\hline & Total & 6483 & 100 \\
\hline
\end{tabular}

Hasil Uji chi square menunjukkan bahwa terdapat hubungan yang bermakna antara status imunisasi dasar dengan membaca surat kabar (P-value 0,009), menonton televisi (Pvalue 0,000$)$, dan frekuensi akses internet $(\mathrm{P}$ value 0,000 ) sedangkan tidak terdapat hubungan yang bermakna antara mendengarkan radio dengan imunisasi dasar (P-value 0,905) (tabel 3). Selanjutnnya dilakukan uji regresi logistik berganda: 1) Seleksi kandidat pada model awal, terdapat 3 variabel yang menjadi kandidat model yaitu membaca surat kabar, menonton televisi dan frekuensi akses internet (P-value < 0,25). 2) Pada model awal, terdapat 1 variabel yang memiliki P-value > 0,05 yaitu membaca surat kabar sehingga harus dikeluarkan dari model. 3) Setelah itu dilakukan perhitungan perubahan OR, namun tidak ada variabel yang memiliki 
perubahan OR >10\%, sehingga variabel membaca surat kabar dikeluarkan secara permanen. Hasil pemodelan akhir regresi logistik berganda menunjukkan ada hubungan yang bermakna antara menonton televisi dan frekuensi akses internet dengan status imunisasi dasar (P-value < 0,05). Variabel yang paling dominan atau paling berpengaruh terhadap status imunisasi dasar adalah menonton televisi dengan OR 2,268, artinya Ibu yang tidak pernah menonton televisi 2,268 kali berisiko memiliki status imunisasi anak yang tidak lengkap dibandingkan dengan ibu yang menonton televisi 1 kali seminggu, setelah dikontrol variabel frekuensi akses internet (tabel 4).

Tabel 3. Hubungan Akses Media dengan Status Imunisasi Dasar di Indonesia tahun 2017.

\begin{tabular}{|c|c|c|c|c|c|c|c|}
\hline \multirow{3}{*}{ Akses Media dan Asuransi } & \multicolumn{6}{|c|}{ Status Imunisasi } & \multirow[t]{3}{*}{ P-Value } \\
\hline & \multicolumn{2}{|c|}{$\begin{array}{c}\text { Tidak } \\
\text { Lengkap }\end{array}$} & \multicolumn{2}{|c|}{ Lengkap } & \multicolumn{2}{|c|}{ Total } & \\
\hline & n & $\%$ & $\mathbf{n}$ & $\%$ & $\mathbf{n}$ & $\%$ & \\
\hline \multicolumn{8}{|l|}{ 1. Membaca surat kabar } \\
\hline Tidak pernah & 1363 & 33,5 & 2704 & 66,5 & 4067 & 100 & \multirow{3}{*}{0,009} \\
\hline Kurang dari 1 kali seminggu & 557 & 30,0 & 1302 & 70,0 & 1859 & 100 & \\
\hline 1 kali seminggu & 164 & 29,4 & 393 & 70,6 & 557 & 100 & \\
\hline \multicolumn{8}{|l|}{ 2. Mendengarkan radio } \\
\hline Tidak pernah & 1308 & 32,2 & 2752 & 67,8 & 4060 & 100 & \multirow[b]{3}{*}{0,905} \\
\hline Kurang dari 1 kali seminggu & 542 & 31,8 & 1164 & 68,2 & 1706 & 100 & \\
\hline 1 kali seminggu & 234 & 32,6 & 483 & 67,4 & 717 & 100 & \\
\hline \multicolumn{8}{|l|}{ 3. Menonton televisi } \\
\hline Tidak pernah & 131 & 52,4 & 119 & 47,6 & 250 & 100 & \multirow[b]{3}{*}{0,000} \\
\hline Kurang dari 1 kali seminggu & 251 & 33,8 & 491 & 66,2 & 742 & 100 & \\
\hline 1 kali seminggu & 1702 & 31,0 & 3789 & 69,0 & 5491 & 100 & \\
\hline \multicolumn{8}{|l|}{ 4. Frekuensi akses internet } \\
\hline Tidak pernah & 1253 & 35,1 & 2314 & 64,9 & 3567 & 100 & \multirow{4}{*}{0,000} \\
\hline Kurang dari 1 kali seminggu & 48 & 24,9 & 145 & 75,1 & 193 & 100 & \\
\hline 1 kali seminggu & 177 & 27,7 & 463 & 72,3 & 640 & 100 & \\
\hline Hampir setiap hari & 606 & 29,1 & 1478 & 70,9 & 2084 & 100 & \\
\hline
\end{tabular}

Tabel 4. Analisis Multivariat Akses Media dengan Status Imunisasi Dasar di Indonesia tahun 2017.

\begin{tabular}{lccccccc}
\hline Variabel & B & SE & df & Sig & Exp (B) & Lower & Upper \\
\hline Menonton televisi & & & 2 & 0,000 & & & \\
Menonton televisi (1) & 0,698 & 0,149 & 1 & 0,000 & 2,010 & 1,500 & 2,694 \\
Menonton televisi (2) & 0,819 & 0,131 & 1 & 0,000 & 2,268 & 1,754 & 2,931 \\
Frekuensi akses internet & & & 3 & 0,000 & & & \\
Frekuensi akses internet (1) & 0,445 & 0,170 & 1 & 0,009 & 1,560 & 1,119 & 2,176 \\
Frekuensi akses internet (2) & 0,297 & 0,096 & 1 & 0,002 & 1,345 & 1,116 & 1,622 \\
Frekuensi akses internet (3) & 0,242 & 0,060 & 1 & 0,000 & 1,274 & 1,132 & 1,433 \\
Constant & $-0,139$ & 0,127 & 1 & 0,273 & 0,870 & & \\
\hline
\end{tabular}

Berdasarkan analisis multivariat, televisi menjadi media yang paling dominan berpengaruh terhadap status imunisasi dasar di Indonesia. Terdapat beberapa alasan yang mendasari besarnya pengaruh televisi terhadap imunisasi. Alasan pertama adalah televisi merupakan suatu saluran sumber informasi yang paling banyak digemari oleh masyarakat Indonesia. Hampir setiap keluarga di Indonesia memiliki perangkat televisi di rumah. 
Keberadaan televisi telah menjadi kebutuhan primer sebuah keluarga sebagai sumber hiburan, berita, informasi dan media periklanan. Keberadaan televisi tentu sangat berdekatan dengan kehidupan masyarakat. Kelengkapan imunisasi seorang anak juga dipengaruhi oleh media informasi yang diakses oleh keluarga. Berdasarkan penelitian Mbengue (2017) juga menunjukkan terdapat hubungan signifikan antara status imunisasi dengan keluarga yang mempunyai akses terhadap televisi. ${ }^{21,22,23}$

Televisi juga merupakan media yang menggabungkan audio dan visualisasi sehingga televisi dapat di kategorikan menjadi media multimodal yang melibatkan banyak aspek seperti audio dan visual. Media dengan multimodal ini akan menghasilkan retensi memori lebih tinggi daripada unimodal. Retensi memori ini penting pada sebuah perubahan pengetahuan, sikap bahkan perilaku. Retensi dapat diartikan sebagai proses mengingat kembali. Dalam teori proses mengingat retensi merupakan tahap kedua proses mengingat untuk menyimpan informasi (storage) yang telah diperoleh sebelumnya. Tahap sebelumnya adalah proses belajar sebagai tahap pertama dalam mengingat berupa endcoding, penyandian atau pencatatan sandi. Tahap ketiga yakni retrival (retrieval) sebagai proses mengingat untuk mencari kembali informasi yang telah disimpan (decoding). 6,7

Selain itu, televisi merupakan saluran informasi yang memapar banyak pancaindra seperti panca indra pendengaran dan penglihatan. Hasil dari pencitraan indra tersebut akan ditangkap dan disimpan dalam gudang indrawi manusia (sensory starage). Sensory starage dapat berupa memori ikonis (diperoleh melalui indra penglihatan) dan memori ekonis (diperoleh melalui indra pendengaran). Saluran televisi menyuguhkan input kedua memori tersebut. Hal tersebut menjadikan televisi menjadi saluran media yang memiliki pengaruh lebih banyak kepada memori dan input informasi pada individu. ${ }^{8}$

Alasan lainnya adalah aplikasi televisi menjelaskan sebuah informasi lebih konkret dibanding dengan media lainnya. Hal tersebut dikarenakan televisi memuat sesuatu pesan dengan pendekatan auditif dan visualisasi. Teori Dale's Cone of Experience, yang menjelaskan tentang model berbagai jenis media audiovisual dari yang paling abstrak hingga paling konkrit, semakin konkret pengalaman yang diberikan akan lebih menjamin terjadinya proses belajar. Kelebihan lain dari televisi adalah suguhan informasinya lebih konkret dengan penggambaran visual dan audio dalam penyampaiannya sehingga televisi dapat menjadi sumber pembelajaran yang baik bagi masyarakat.

Hasil penelitian ini juga menunjukkan hubungan yang signifikan antara frekuensi akses internet dengan status imunisasi pada anak di Indonesia. Hal ini juga dibuktikan oleh hasil penelitian Glanz (2017) yaitu ada pengaruh positif antara memberikan informasi vaksin berbasis web dengan aplikasi media sosial selama kehamilan dengan perilaku vaksin orang tua (rasio odds $[\mathrm{OR}]=1,92 ; 95 \%[\mathrm{CI}], 1,07$ 3,47). Pada saat yang sama, media sosial mungkin memiliki potensi untuk menghilangkan kekhawatiran orang tua terhadap vaksin dan peningkatan tingkat imunisasi. ${ }^{9,10}$

Sumber informasi mengenai imunisasi paling banyak diperoleh masyarakat melalui situs internet. Media sosial seperti facebook juga mempunyai peranan penting dalam membangun kesadaran imunisasi orang tua. Namun informasi dapat berpengaruh negatif dan terkadang membuat keraguan seorang terhadap pembeiran imunisasi. Hasil intervensi oleh ECDC (2017) menunjukkan bahwa semakin banyak keluarga mencari informasi kesehatan secara online, yaitu $79 \%$ ibu menggunakan media sosial setiap hari dan $80 \%$ pengguna internet mencari informasi kesehatan online. ${ }^{11,24,25}$

Berdasarkan hasil penelitian Survei Kesehatan Demografis dari 13 negara subSahara (2004-2010), terdapat efek penggunaan media (radio dan televisi) dengan hubungan antara SES (Status Ekonomi Sosial) dan penggunaan vaksin. Temuan ini menunjukkan bahwa media masa dapat menjadi alat penting untuk upaya masa depan untuk mengurangi 
kesenjangan kesehatan antara anak-anak dari latar belakang sosial ekonomi tinggi dan rendah. Menurut hasil metanalisis dari 21 studi yang meneliti pengaruh intervensi kesehatan dengan menggunakan situs jejaring sosial (SNS) terhadap perubahan perilaku kesehatan menunjukkan efek yang efektif secara umumnya, tetapi efeknya dimoderasi oleh topik kesehatan, fitur metodologi, dan fitur peserta. Platform media sosial menjadi semakin populer di kalangan populasi di dunia, termasuk Twitter, Snapchat, dan Instagram. ${ }^{12,14,17}$

Pada penelitian ini, juga menunjukkan bahwa membaca koran memiliki hubungan yang signifikan dengan status imunisasi dasar. Sedangkan mendengarkan radio tidak memiliki hubungan yang signifikan dengan imunisasi dasar. Kelengkapan imunisasi seorang anak juga dipengaruhi oleh media informasi yang diakses oleh keluarga. Media masa merupakan media yang penting untuk memberikan info terkait imunisasi. Menurut penelitian yang dilakukan Alshammari (2018), sebanyak 43,1 \% Masyarakat merasa puas dengan informasi tentang vaksinasi yang disediakan oleh media. Akses orangtua untuk informasi berkala dan konseling tentang manfaat kesehatan dari vaksinasi adalah kontributor yang signifikan untuk keyakinan vaksin dan penerimaan serta tingkat imunisasi yang tinggi. ${ }^{15,16,21,22}$

Melalui Peraturan Menteri Kesehatan Republik Indonesia Nomor 12 Tahun 2017, pemerintah menggerakkan peran aktif masyarakat dalam pelaksanaan pelayanan imunisasi program di Indonesia melalui beberapa kegiatan di antaranya pemberian informasi melalui media cetak, media sosial, media elektronik dan media luar ruang. Pemberian informasi dapat meningkatkan pengetahuan ibu. Pengetahuan ibu yang tinggi dapat mempengaruhi kelengkapan imunisasi dasar pada anak. Di sisi lain, tenaga kesehatan memberikan peranan penting dalam informasi imunisasi yang tepat, sehingga diharapkan tenaga kesehatan dapat memberikan edukasi imunisasi yang tepat melalui berbagai media termasuk internet dan televisi. ${ }^{18,20}$

\section{SIMPULAN DAN SARAN}

Hasil penelitian ini menunjukkan bahwa terdapat pengaruh antara membaca surat kabar, menonton televisi, frekuensi akses internet dengan status imunisasi dasar di Indonesia (Pvalue $<0,05$ ). Hasil multivariat menunjukkan variabel menonton televisi merupakan variabel yang paling dominan terhadap status imunisasi dasar di Indonesia. Saran dari penelitian ini adalah pemerintah terus menggalakkan sosialisasi yang akurat tentang pentingnya imunisasi dasar di media, khususnya di media televisi.

\section{UCAPAN TERIMA KASIH}

Terima kasih diucapkan kepada Lembaga Penelitian Universitas Muhammadiyah Prof. DR. HAMKA sebagi pemberi dana dalam penelitian ini. Selain itu, ucapan terima kasih juga disampaikan kepada BKKBN yang telah memberikan data SDKI 2017.

\section{REFERENSI}

1. WHO. Immunization coverage [Internet]. 2019 [cited 2020 Apr 1]. Available from: https://www.who.int/news-room/factsheets/detail/immunization-coverage

2. WHO. Immunization [Internet]. WHO. 2019 [cited 2020 Apr 11]. Available from: https://www.who.int/news-room/facts-inpictures/detail/immunization

3. WHO. Pneumonia [Internet]. who. 2019 [cited 2020 Apr 11]. Available from: https://www.who.int/news-room/factsheets/detail/pneumonia

4. Musniati N, Sartika RAD. International Journal of Agriculture Extension and Social Development The existence of livestock as a dominant risk factor of pneumonia among Indonesian children aged 12-59 months. 2019;2(1):7-10. Available from: http://www.extensionjournal.com/article/view/1 6/1-1-10

5. Badan kependudukan dan keluarga berencana nasional. Survei Demografi dan Kesehatan Indonesia 2017. Indonesia: BKKBN; 2017. p. $1-2$.

6. Puspita D. Retensi pengetahuan, sikap, dan perilaku pasca pelatihan gizi seimbang pada siswa kelas 5 dan 6 di 10 Sekolah Dasar terpilih Kota Depok. Univ Indones. 2012;1-123.

7. Udomon I, Xiong C, Berns R, Best K VN. 
Visual, audio, and kinesthetic effects on memory retention and recall. J Adv Student Sci. 2013;1:1-29.

8. Rakhmat J. Psikologi komunikasi. Bandung: Remadja Rosdakarya; 2000.

9. Wagner NM, Narwaney KJ, Kraus CR, Glanz JM, Xu S, Shoup JA, et al. Web-based Social Media Intervention to Increase Vaccine Acceptance: A Randomized Controlled Trial. 2020;140(6).

10. Betsch C, Renkewitz F, Betsch T, Ulshöfer C. The Influence of Websites on Perceiving. J Health Psychol. 2010;15(3):446-55.

11. ECDC. Catalogue of interventions addressing vaccine hesitancy [Internet]. Stockholm: ECDC; 2017. 38-42 p. Available from: https://www.ecdc.europa.eu/sites/default/files/d ocuments/Catalogue-interventions-vaccinehesitancy.pdf

12. Jung M, Lin L, Viswanath K. Effect of media use on mothers ' vaccination of their children in sub-Saharan Africa. Vaccine [Internet]. 2015;33(22):2551-7. Available from: http://dx.doi.org/10.1016/j.vaccine.2015.04.021

13. WHO. Immunization [Internet]. WHO. 2019 [cited 2020 Apr 1]. Available from: https://www.who.int/news-room/facts-inpictures/detail/immunization

14. Yang Q. Are Social Networking Sites Making Health Behavior Change Interventions More Effective? A Meta-Analytic Review. J Health Commun [Internet]. 2017;22(3):223-33. Available from: http://dx.doi.org/10.1080/10810730.2016.12710 65

15. Alshammari TM, Subaiea GM, Hussain T, Moin A, Yusuff KB. Parental perceptions , attitudes and acceptance of childhood immunization in Saudi Arabia: A cross sectional study. Vaccine [Internet]. 2017; Available from: https://doi.org/10.1016/j.vaccine.2017.11.050

16. Larson HJ, Cooper LZ, Eskola J, Katz SL, Ratzan S. New Decade of Vaccines 5 Addressing the vaccine confi dence gap. 2011;378.

17. Duggan M. Mobile messaging and social media 2015 [Internet]. Pew Research Center. 2015 [cited 2020 Apr 2]. Available from: https://www.pewresearch.org/internet/2015/08/1 9/mobile-messaging-and-social-media-2015/
18. Kemenkes RI. Peraturan Menteri Kesehatan Republik Indonesia Nomor 12 Tahun 2017 Tentang Penyelenggaraan Imunisasi [Internet]. Kemenkes, RI. Kemenkes RI; 2017. Available from:

http://hukor.kemkes.go.id/uploads/produk_huku m/PMK_No._12_ttg_Penyelenggaraan_Imunisa si_.pdf

19. Kementerian Kesehatan Republik Indonesia. Pusat Data dan Informasi Kementerian Kesehatan: Situasi dan Analisis Imunisasi. Jakarta; 2014.

20. Suraya I, Hidayati, Ariesta Putranti R, Apriyanto, Julia. Peran Tenaga Kesehatan Dalam Perilaku Imunisasi Dasar Pada Peserta Didik PAUD Kelurahan Ciampea dan Kalibata. J Surya Med. 2019;5(1):155 -61.

21. Al-lela O.Q. B, Bahari M.B, Al-Qazaz H.K, Salih M.R.M, Jamshed SQ, Elkalmi, R.M. (2014). Are parents' knowledge and practice regarding immunization related to pediatrics' immunization compliance? A mixed method study. 14(20).

22. Ames, H, Glenton, C, Lewin, S. (2017). Parents' And Informal Caregivers' Views And Experiences Of Communication About Routine Childhood Vaccination: A Synthesis Of Qualitative Evidence. Cochrane Database Of Systematic Reviews, 2,

23. Mbengue, M.A, Sarr, M., Faye, A., Badiane, O., Camara, F.B.N., Mboup, S., dan Dieye, T.N, (2017). Determinants Of Complete Immunization Among Senegalese Children Aged 1223 Months: Evidence From The Demographic And Health Survey. BMC Public Health, 17, 630 -639.

24. Yusmawati. (2018). Group Faceebook Gesamun Sebagai Media Baru Dalam Upaya Menyadarkan Masyarakat Akan Pentingnya Imunisasi. eJournal, 9 (1).

25. Arifianto. (2017). Pro Kontra Imunisasi Agar Tak Salah Memilih Demi Kesehatan Buah Hati. Jakarta : Noura Books. 